\title{
HUBUNGAN LAMA PEMAKAIAN DENGAN EFEK SAMPING KONTRASEPSI SUNTIK 3 BULAN PADA AKSEPTOR KB
}

\author{
Rahmah Juliani Siregar ${ }^{1}$, Maryam Latifah Harahap ${ }^{2}$ \\ ${ }^{1}$ Prodi S.1 Ilmu Kesehatan STIKes Darmais Padangsidimpuan, \\ Email : rahmahjulianisiregar@gmail.com \\ ${ }^{2}$ Prodi D-III Kebidanan Akademi Kebidanan Darmais Padangsidimpuan \\ Email : maryamlatifahharahap@gmail.com
}

\begin{abstract}
The family planning program is one of the government's efforts to improve the quality of the population. One type of effective contraception is the choice of mothers is the 3-month injection KB because it is safe, effective, simple and expensive. However, the 3-month injection KB also has many side effects such as amenorrhea, spotting and menorrhagia like other contraceptives, there are complaints of nausea, headache and dizziness. The purpose of this study was to determine the relationship between duration of use and side effects of 3-month injections on family planning acceptors. This study was an analytic study with a cross sectional approach with the total population of 50 peoples and sampling techniques, the total population of 92 acceptors of 3-month injection KB and analyzed by Chi-square test.The results showed that there was a relationship between duration of use and side effects of 3-month injections on family planning acceptors in the Puskesmas Biru Tapanuli Selatanthe years 2021. with P value $=0.000(\alpha<0.05)$ the concluded that there is a relationship between duration of use and the occurrence of side effects in family planning acceptors, it is recommended to health workers to assist in determining suitable contraception for acceptors in an effort to minimize the occurrence of side effects of 3-month injections of family planning acceptors.
\end{abstract}

Keywords: duration of use, side effects, family planning acceptors

\section{PENDAHULUAN}

Program Program KB merupakan salah satu program pemerintah dalam upaya meningkatkan kualitas penduduk. Adanya perubahan paradigma program $\mathrm{KB}$ dari pendekatan pengendalian populasi dan penurunan fertilitas ke arah pendekatan kesehatan, menunjukkan bahwa semakin pentingnya kualitas pelayanan KB. Kasus pergantian dini metode $\mathrm{KB}$ merupakan salah satu indikator adanya penurunan kualitas pelayanan $\mathrm{KB}$, yang menunjukkan kurangnya informasi kepada akseptor mengenai permasalahan kontrasepsi, termasuk efek samping $\mathrm{KB}$ suntik yang menimbulkan efek samping utama gangguan pola haid yang merupakan sebab utama dari penghentian kontrasepsi suntik (Hartanto, 2018).

Salah satu jenis kontrasepsi efektif yang menjadi pilihan kaum ibu adalah $\mathrm{KB}$ suntik. Hal ini disebabkan karena aman, efektif, sederhana dan murah. Cara ini mulai disukai masyarakat kita dan diperkirakan setengah juta pasangan memakai kontrasepsi suntikan untuk mencegah kehamilan (Mochtar, 2008). Namun demikian KB suntik juga memiliki banyak efek samping berupa amenorea, spotting (bercak darah) dan menoragia seperti halnya dengankontrasepsi lainnya, maka dijumpai pula keluhan mual, sakit kepala, pusing dan berat badan bertambah (Glasier, 2012).

Berdasarkan penelitian yang dilakukan oleh WHO (World Health Organization) ternyata setelah kontrasepsi suntik 
dihentikan terjadi sedikit keterlambatan dalam kembalinya kesuburan, tetapi tidak ditemukan bukti bahwa kontrasepsi suntikan mengganggu fertilitas secara permanen. Lebih dari 50 persen yang pernah memakai $\mathrm{KB}$ suntik akan mengalami haid kembali setelah 6 bulan dan kira-kira 85 persen setelah satu tahun, lebih dari 60 persen yang pernah memakai KB suntik sudah hamil dalam waktu satu tahun dan lebih dari 90 persen dalam waktu 2 tahun (Hartanto, 2014).

Berdasarkan hasil Survey Sosial Ekonomi Nasional (Susenas), di Indonesia pilihan alat kontrasepsi suntik masih terbanyak diminati oleh para wanita yang berstatus kawin dengan persentase 58,7 persen untuk kontrasepsi suntik (Depkes RI, 2013).Jenis kontrasepsi suntik yang disediakan dalam program KB Nasionalsalah satunya adalah kontrasepsi suntik 3 bulan (depoprovera $150 \mathrm{mg}$ ) yang diberikan setiap tiga bulan. (Hartanto,2014).

Berdasarkan profil kesehatan (2016) pencapaian peserta KB aktif di Indonesia mencapai 35.202.908 peserta dimana peserta $\mathrm{KB}$ aktif yang menggunakan $\mathrm{KB}$ suntikan 16.734.917 (47,54\%), pil sebesar 8.300.362 $(23,58 \%)$, kondom $1.110 .341(3,15 \%)$, implant sebesar $3.680 .816(10,46)$, MOP 241.642 (0,69\%), MOW 1.238.749 (3,52\%), IUD $3.89 .081(11,07 \%)$ dan pencapaian peserta KB baru 7.761.961 peserta dengan jumlah PUS 47.019.002 jiwa (Kemenkes, 2014).

Di Sumatera Utara salah satu metode kontrasepsi yang banyak digunakan adalah kontrasepsi hormonal. Saat diperkenalkan pada tahun 1960, kontrasepsi hormonal menjadi sebuah perubahan drastis dari metode-metode tradisional sebelumnya. Metode kontrasepsi hormonal dianggap salah satu metode dengan tingkat efektivitas yang tinggi, tetapi pada pelaksanaannya penggunaan kontrasepsi ini banyak mengalami kendala-kendala baik yang disebabkan efek samping kontrasepsi itu sendiri terutama masalah terjadinyagangguan pola haid (Hartanto, 2014).

Tahun 2017 target nasional cakupan akseptor KB aktif adalah $70 \%$, kenyataannya tahun 2017 peserta KB aktifdi Tapanuli Selatan masih jauh dari target yang diharapkan, dimana hanya24.851 $(58,65 \%)$ peserta KB aktif dengan jenis metode kontrasepsi mayoritas yang dipakai adalah kontrasepsi suntikan 10.027 (40,29

$\%$ ) di susul metode kontrasepsi pil, implan dan kontrasepsi pria (kontap) (BKKBN, 2017).

Berdasarkan survey awal yang dilakukan peneliti, dari 10 orang akseptorKB suntik 3 bulan (depoprovera) diketahui 8 orang mengalami gangguan haiddengan pemakaian lebih dari satu tahun dan 2 orang mengalami sakit kepala, dengan lama pemakaian kurang dari satu tahun. Didukung oleh banyaknya akseptor KB suntik 3 bulan (depoprovera) dengan latar belakang lama pemakaian kontrasepsi yang berbeda-beda serta banyaknya jenis efek samping, oleh karena itu peneliti tertarik untuk meneliti hubungan lama pemakaian dengan efek samping kontrasepsi suntik 3 bulan pada akseptor KB di Wilayah Kerja Puskesmas Biru Tapanuli Selatan Tahun 2021.

Tujuan penelitian ini adalah Untuk mengetahui hubungan lama pemakaian dengan efek samping kontrasepsi suntik 3 bulan pada akseptor KBdi Wilayah Kerja Puskesmas Biru Tapanuli Selatan Tahun 2021.

\section{METODE PENELITIAN}

Jenis Penelitian ini merupakan penelitian survei analitik dengan menggunakan pendekatan cross sectional, untuk mengetahui hubungan lama pemakaian dengan efek samping kontrasepsi suntik 3 bulan pada akseptor KB. 
Populasi dalam penelitian ini adalah seluruh akseptor KB suntik 3 bulan yang ada di di Wilayah Kerja Puskesmas Biru Tapanuli Selatan Tahun 2021 sebanyak 50 orang.

Sampel dalam penelitian inidilakukan secara total sampling, dimana semua populasi dijadikan sebagai sampel sebanyak 50 orang dengan instrument penelitian kuiosoner menggunakan uji chi square.

\section{HASIL}

\section{Analisis Univariat}

\section{Distribusi Frekuensi Efek Samping KB Suntik 3 Bulan pada Akseptor KB}

\begin{tabular}{|c|c|c|c|}
\hline No & Efek Samping & $\bar{F}$ & $\%$ \\
\hline 1 & Gangguan Haid & 28 & 56 \\
\hline 2 & $\underline{\text { Sakit Kepala }}$ & $\underline{22}$ & 44 \\
\hline & Total & $\underline{50}$ & $\underline{100}$ \\
\hline
\end{tabular}

Dari tabel di atas diketahui bahwa akseptor KB yang mengalami efeksamping KB Suntik 3 Bulan berupa gangguan haid sebanyak 28 orang (56\%), dan yang mengalami sakit kepala sebanyak 22 orang (44\%).

\section{Distribusi Frekuensi Responden berdasarkan Lama Pemakaian}

\begin{tabular}{cccc}
\hline No & Lama Pemakaian & F & \% \\
1 & $\leq 1$ tahun & 19 & 38 \\
2 & $>1$ tahun & 31 & 62 \\
\hline \multicolumn{1}{c}{ Total } & $\underline{\mathbf{5 0}}$ & $\underline{\mathbf{1 0 0}}$ \\
\cline { 2 - 4 }
\end{tabular}

Dari tabel di atas diketahui bahwa responden yang lama pemakaian kurang dari 1 tahun sebanyak 19 orang (38\%) dan lama pemakaian lebih dari 1 tahun sebanyak 31 orang $(62 \%)$.

\section{Analisis Bivariat}

Hubungan Lama Pemakaian dengan Efek Samping KB Suntik 3 Bulan

\begin{tabular}{|c|c|c|c|c|c|c|c|}
\hline \multirow{3}{*}{ No } & \multirow{3}{*}{$\begin{array}{l}\text { Lama } \\
\text { pemak } \\
\text { aian }\end{array}$} & \multicolumn{4}{|c|}{$\begin{array}{c}\text { EfekSamping KB } \\
\text { Suntik } 3 \text { bln }\end{array}$} & \multirow{2}{*}{\multicolumn{2}{|c|}{ total }} \\
\hline & & \multicolumn{2}{|c|}{$\begin{array}{l}\text { Ganggu } \\
\text { an Haid }\end{array}$} & \multicolumn{2}{|c|}{$\begin{array}{c}\text { Sakit } \\
\text { Kepala }\end{array}$} & & \\
\hline & & $\mathrm{n}$ & $\%$ & $\mathrm{n}$ & $\%$ & $\mathbf{N}$ & $\%$ \\
\hline 1 & $\begin{array}{l}\leq 1 \\
\text { tahun }\end{array}$ & 12 & 24 & 10 & 20 & 22 & 44 \\
\hline 2 & $\begin{array}{l}>1 \\
\text { tahun }\end{array}$ & 12 & 24 & 16 & 32 & 28 & 56 \\
\hline
\end{tabular}

Berdasarkan tabel di atas dapat dilihat bahwa dari 22 responden dengan lama pemakaian kurang dari 1 tahun yang mengalami efek samping KB Suntik 3 Bulan berupa gangguan haid yaitu 12 orang (24\%), yang mengalami sakit kepala 10 orang( $22 \%)$. Dari 28 responden lama pemakaian lebih dari 1tahun yang mengalami efek samping KB Suntik 3 Bulan berupa gangguan haid 12 orang $(24 \%)$, yang mengalami sakit kepala 16 orang (32\%).

Berdasarkan hasil uji statistic Chi_square diperoleh nilai $p$ value $=0,001(\alpha$ $<0,05)$, sehingga Ho ditolak. Yang artinya ada hubungan yang signifikan antara lama pemakaian dengan efek samping KB Suntik 3 Bulan pada akseptor KB.

\section{PEMBAHASAN}

\section{Hubungan Lama Pemakaian dengan Efek Samping KB Suntik 3 Bulan}

Kontrasepsi suntik juga bisa mencegah kehamilan karena memicu pengentalan cairan atau lendir di leherrahim. Hal ini membuat sperma jadi sulitmencapai rahim dan bertemu dengan sel telur.Hormon dalam alat kontrasepsi ini dapat bertahan selama 12 minggu atau 3 bulan untuk mencegah kehamilan. Namun, 
penggunaan $\mathrm{KB}$ suntik tidak bisa melindungi dari penyakit seksual menular.

Berdasarkan tabel di atas dapat dilihat bahwa dari 22 responden dengan lama pemakaian kurang dari 1 tahun yang mengalami efek samping KB Suntik 3 Bulan berupa gangguan haid yaitu 12 orang (24\%), yang mengalami sakit kepala 10 orang(22\%). Dari 28 responden lama pemakaian lebih dari 1 tahun yang mengalami efek samping $\mathrm{KB}$ Suntik 3 Bulan berupa gangguan haid 12 orang $(24 \%)$, yang mengalami sakit kepala 16 orang (32\%).

Hasil analisa bivariat melalui uji statistik dengan menggunakan ujiChi_square diperoleh nilai $p$ value $=0,001(\alpha<0,05))$, hal ini menunjukkan bahwa ada hubungan lama pemakaian KB Suntik 3 Bulan dengan terjadinya efek samping. Dari 33 orang responden dengan lama pemakaian kurang dari 1 tahun mayoritas mengalami sakit kepala, hal ini dipengaruhi karena belum terlalu banyak penambahan progesteron, tetapi lebih kepada reaksi tubuh terhadap progesteron sehingga hormon progesteron mengalami penekanan yang berujung pada penekanan syaraf otak, stress dan riwayat penyakit migrain.

Responden dengan lama pemakaian lebih dari 1 tahun mayoritas mengalami efek samping gangguan haid, hal ini disebabkan pada pemakaian KB Suntik 3 Bulan dalam rentang waktu yang lebih lama cenderung lebih mempengaruhi perubahan progesteron karena terjadi penambahan. Penambahan progesteron inilah yang menyebabkan terjadinya pelebaran pembuluh darah vena di endometrium, yang akhirnya rapuh dan terjadi perdarahan lokal. menyebabkan hormon dalam tubuh tidak teratur sehingga berpengaruh terhadap terjadinya gangguan haid. perdarahan irregular (tidak teratur), amenorea dan perubahan frekuensi, lama dan jumlah darah yang hilang.

Pada pemakaian lama, perubahan siklus menstruasi adalah efek samping yang paling umum. Pengguna suntikan KB dapat mengalami pendarahan atau spotting yang tidak teratur. Setelah setahun penggunaan KB suntik sekitar 50 persen wanita berhenti haid. Haid biasanya akan kembali dialamisetelah suntikan dihentikan (Hartanto, 2014).

Pola haid yang normal dapat menjadi amenore, perdarahan ireguler, perdarahan bercak, perdarahan dalam frekuensi yang lama. Efek pada pola haid tergantung pada lama pemakaian. Perdarahan inter-menstrual dan perdarahan bercak berkurang dengan jalannya waktu, sedangkan kejadian amenore bertambah besar.Insiden yang tertinggi dari amenore diduga berhubungan dengan atropi endometrium. Sedangkan sebab-sebab dari perdarahan ireguler masih belum jelas dan nampaknya tidak adahubungan dengan perubahan-perubahan dalam kadar hormon. DMPA lebih sering menyebabkan perdarahan dan amenorea (Hartanto, 2014).

Menurut asumsi peneliti pada pemakaian KB Suntik 3 Bulan dalam rentang waktu yang lebih lama cenderung lebih mempengaruhi perubahan progesteron karena terjadi penambahan. Akibatnya terjadi penumpukan yang mengakibatkan hormon dalam tubuh tidak teratur sehingga berpengaruh terhadap terjadinya gangguan haid.Sedangkan sakit kepala yang dialami responden bisa disebabkan reaksi tubuh terhadap progesteron, stress dan riwayat penyakit migrain yang diderita responden.

\section{SIMPULAN}

Menurut Hartanto (2014) gangguan pola haid yang terjadi tergantung pada lama pemakaian, dimana gangguan pola haidyang terjadi seperti perdarahan bercak/flek, Ada hubungan yang signifikan antara lama pemakaian dengan efek samping KB Suntik 3 Bulan pada akseptor $\mathrm{KB}$ dengan nilai $\mathrm{p}$ value $=$ 0,001 


\section{REFERENSI}

Baziad, Ali. 2002. Kontrasepsi Hormonal. Jakarta : YBP

BKKBN. 2003.Materi Konseling. Jakarta:BKKBN

BKKBN.2008.Penduduk Indonesia bertambah 3 Juta setiap tahun. www.bkkbn.go.id/jateng. tanggal 11 Juli 2008.23:18

Daryanto, S.2018. Kamus Lengkap Bahasa Indonesia. Surabaya: Apollo.

Glasier, A. Gebbie, A. 2012. Keluarga Berencana KesehatanReproduksi. Edisi 4. Buku Kedokteran. Jakarta: EGC

Hartanto, H. 2014. Keluarga Berencana dan Kontrasepsi. Cetakan Kelima. Jakarta: Pustaka Sinar Harapan

Iryanto, K. 2012. Keluarga Berencana untuk Paramedis dan Nonmedis. Cetakan Pertama. Bandung: Yrama Widya

Manuaba ,I.B.G. 2008. Memahami Kesehatan Reproduksi Wanita. Jakarta: Arcan.

Saifuddin, A.B. 2016. Buku Panduan Praktis Pelayanan Kontrasepsi. Jakarta: Yayasan Bina pustaka Sarwono Prawirohardjo

Winkjosastro, H. 2016. Ilmu Kebidanan. Edisi Ketiga Cetakan Kedelapan. Jakarta: Yayasan Bina Pustaka Sarwono Prawirohardjo

Winkjosastro, H. 2017. Ilmu Kandungan. Edisi Kedua Cetakan Kelima. Jakarta: Yayasan Bina Pustaka Sarwono Prawirohardjo
Arwin, 2010. Proceeding of the National Academy of Sciencees [Diakses 11 Februari 2019].

Depkes RI 2013. Masalah Kependudukan dan Program KB. [Online]. Dari:http://kesmaspro.blogspot.com/2 018/05/masalah-kependudukandaprogram-kb.html [Diakses 12 Februari 2019].

Olvista, 2012. Depoprovera (Suntik KB) [Online]. Dari: http://olvista.com/kesehatan/depoprovera-suntik-kb-\%E2\%80\%93manfaat-efek-samping-dankontraindikasinya [Diakses 13 Februari 2019].

Tanjung, S. 2010. Akseptor Aktif di Tapsel. Waspada Online 2018. [Diakses 09 Februari 2019]

Saifuddin, Abdul Bari. 2003. Buku Panduan Praktis Pelayanan Kontrasepsi.Jakarta: YBP-Sarwono P

Siswosudarmo, Moch. Anwar, Ova Emilia. 2001. Teknologi Kontrasepsi. Yogyakarta : Gadjah Mada University Press

Varney, Hellen (et.all). 2006. Buku Ajar Asuhan Kebidanan Edisi 4 Volume 1. Jakarta : EGC

Hartanto, Hanafi. 2004. Keluarga Berencana dan Kontrasepsi. Jakarta : Pustaka Sinar Harapan 